C2019. Licensed under the Creative Commons Attribution-NonCommercial-NoDerivatives 4.0 International http://creativecommons.org/about/downloads

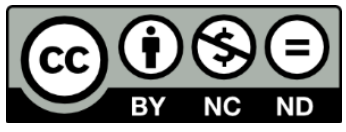

This is not the version of record. The full published version can be found at: https://doi.org/10.1016/j.econlet.2019.108895 


\title{
Extraneous menu-effects influence financial decisions made by pension trustees
}

\author{
Leonardo Weiss-Cohen \\ University of Leeds
}

\author{
Peter Ayton \\ City University of London
}

\author{
Iain Clacher \\ University of Leeds
}

\begin{abstract}
Pension scheme trustees are responsible for the investment decisions of future generations' retirement assets. However, behavioural finance research has mostly focussed on retail investors. While trustees are relatively sophisticated investors, they are not immune from biases. Across three experiments, we tested 252 pension scheme trustees for the influence of extraneous manipulations to the menu of options on investment decisions. Trustees were influenced by changes to the menu item mix, context, and layout. Care should therefore be taken when preparing information presented to trustees, in order to reduce biases that can be detrimental to pension outcomes.
\end{abstract}

\section{Introduction}

Trustees are the true custodians of future generations' retirement incomes, controlling US\$27.6 trillion in pension fund assets in the OECD countries in 2018, equivalent to $57 \%$ of their GDP. ${ }^{1}$ The ubiquity of behavioural finance biases with individual investors is well-established (for a comprehensive review, see Barberis \& Thaler, 2003), but its extension into institutional investors such as pension trustees remains relatively unexplored. This is a surprising oversight, given that the influence of pension trustees is concentrated, systemic and overarching: Investment decisions made by a few trustees can move markets, influence the real economy, and ultimately impact global financial well-being.

It is reasonable to expect that trustees are more financially sophisticated than individual investors (Menkhoff, Schmeling, \& Schmidt, 2009). Pension trustees have access to information and training, have more direct experience in financial markets, and are in constant receipt of advice (Myners, 2001). However, sophistication does not inoculate an individual against behavioural biases (West, Meserve, \& Stanovich, 2012).

The authors acknowledge funding from the Actuarial Research Centre of the Institute and Faculty of Actuaries. We thank Aon for providing access to pension scheme trustees.
Ideally, the financial decisions made by investors should be based on underlying financial fundamentals. In our current research, we explore the influence that extraneous nonfinancial information can have on the financial decisions of trustees, by manipulating the presentation of choice menus. Research has shown that menu design, or "subtle variations in the presentation of options," can influence decisions across many domains (Fox, Ratner, \& Lieb, 2005, p.547), which Dellavigna (2009) has called "menu effects." For example, choices can be influenced by adding irrelevant decoys (Simonson, 1989); by changing the menu size (Sela, Berger, \& Liu, 2009); by framing the same alternative as an extreme or middle choice (Benartzi \& Thaler, 2002); and by changing the menu layout (Dayan \& Bar-Hillel, 2011).

\section{Pension scheme trustees}

We captured data from 252 pension scheme trustees (Age: $M=59.4$ years; Males: $N=210$ ). Access to trustees was provided by Aon UK, an investment consultant. Trustees completed three experiments, ${ }^{2}$ with some trustees participating in multiple experiments.

Our sample included 133 member-nominated and 119

\footnotetext{
${ }^{1}$ OECD Pension Funds in Figures 2018: www.oecd.org/daf/pensions/gps.

${ }^{2}$ Methods, instructions, data and analysis are available online: osf.io/jbmtq/
} 
employer-nominated ${ }^{3}$ trustees. Member-nominated trustees are less sophisticated than their employer-nominated counterparts: The former have less experience working as trustees (8.6 vs. 11.4 years, $p=.004$ ), fewer have professional accreditations $(25 \%$ vs. $51 \%, p<.001)$, work experience in a financial role $(22 \%$ vs. $53 \%, p<.001)$, personal investments (70\% vs. 85\%, $p=.008$ ), and answered fewer correct questions in a 14-question financial literacy test (11.96 vs. 12.72, $p=.003)$. Age, gender, and differences in expertise match those in Clark, Caerlewy-Smith, and Marshall (2007, and references therein) and Myners (2001).

\section{Experiment 1: Menu items}

Benartzi and Thaler (2001) have shown that lay individuals will allocate their own assets evenly across the alternatives provided, regardless of the underlying intrinsic nature of each option. When there were more bond funds than equity funds in the menu of alternatives, participants' allocations were more bond-heavy, and vice-versa - a phenomenon they called "naive diversification." We tested if trustees also diversified naively when distributing assets across different mixes of investment alternatives.

\section{Design}

Trustees $(N=119)$ were asked how they would allocate the assets of a pension scheme across a selection of mutual funds. Our experiment employed a 2 × 3 between-subjects design: there were either two or four fund options; and the options were either balanced (half bonds, half equities), equity-heavy (3/4 equities, $1 / 4$ bonds), or bond-heavy (1/4 equities, $3 / 4$ bonds). In the two-fund condition the imbalance was achieved by introducing a mixed fund, which was half bonds and half equities.

\section{Results}

The investment balance across bonds and equities was influenced by the mix of options available $(F(2,114)=23.75$, $p<.001)$. The mean allocations into bonds in the bond-heavy, balanced, and equity-heavy conditions were $69.7 \%, 61.3 \%$ and $43.9 \%$, respectively. Participants displayed naive diversification, changing allocations according to the mix of options provided, seemingly without basing it on informed principles. Benartzi and Thaler (2001) found a similar pattern with lay individuals, with the proportion of assets invested in bonds depending strongly on the proportion of bond funds offered. This pattern was not different between two and four options $(p=.24)$, and not different between membernominated and employer-nominated trustees $(p=.42)$, with both trustee types showing the same bias.

\section{Experiment 2: Menu context}

Sela et al. (2009) shows that choice is influenced when the same options are labelled differently, changing the context in which the options are evaluated. We tested if a similar extraneous labelling of fund options would affect investment decisions, as proposed by Benartzi and Thaler (2002). We labelled different funds as the "moderate" option in different conditions, therefore putting different options within different contexts.

\section{Design}

Trustees $(N=111)$ were asked to choose a single asset mix across bonds and equities for their pension scheme, from 11 options. Each mix was associated with a predicted range of incomes at retirement. Both income and risk increased with higher allocations into equities, which ranged from $0 \%$ to $100 \%$, in steps of $10 \%$, with the remainder in bonds (adapted from Vlaev, Chater, \& Stewart, 2007).

There were three between-subjects conditions, which manipulated the labelling of some of the options. In the Label$30 \%$ condition, the option with $30 \%$ in bonds was labelled as "moderate," while in the Label-70\% condition the moderate option allocated $70 \%$ into bonds. Two further options were labelled in relation to the moderate: the option with $20 \%$ more bonds than the moderate was labelled "conservative;" and the option with $20 \%$ less bonds was labelled "aggressive." In the Control condition, options were not labelled.

\section{Results}

The proportion of assets allocated to bonds was influenced by the labelling (Kruskal-Wallis $\chi^{2}(2)=6.89, p=.032$ ). In the Label-30\% condition, the mean bond allocation (29.8\%) was lower than in the Label-70\% condition (38.9\%), with

\footnotetext{
${ }^{3}$ Including professional trustees.
} 
the Control condition near the average (34.8\%). This effect was observed only with member-nominated trustees, who are less experienced ( $p_{\text {Holm }}=.033$ ): their modal selection was the $30 \%$-bond fund in the Label-30\% condition and the 60\%bond fund in the Label-70\% condition. This is consistent with past research showing that individuals prefer the middle option in the absence of stable well-defined preferences (Benartzi and Thaler, 2002). Employer-nominated trustees, who are more experienced, displayed stronger preferences resistant to labelling, by choosing the $20 \%$ and $30 \%$ funds most frequently for the Label-30\% and Label-70\% conditions respectively $\left(p_{\text {Holm }}=.73\right)$.

\section{Experiment 3: Menu layout}

We tested how the layout of information and restrictions on search influenced behaviour, using a variation of the "Mouselab" paradigm, which tracks how information is searched (Payne, Bettman, \& Johnson, 1988). Participants were presented with tables containing initially hidden information about mutual funds, in cells they could click-toreveal. The search patterns can be used to determine the relevance of different information items.

\section{Design}

Trustees $(N=122)$ were asked to choose between two mutual funds, across ten different asset classes. The information was presented as a $9 \times 2$ table, with the nine information items along rows (see Figure 1 for the items and their ordering), and the two funds across columns. Each cell was initially hidden, and participants could click to reveal them in any order they chose.

The maximum number of clicks was manipulated according to experimental condition. In the Control condition, they could reveal as many items as they wished. In the Restricted10 and Restricted- 6 conditions, participants were limited to ten and six clicks for each asset class, respectively. After each fund selection, the process started again for the next asset class.

\section{Results}

We calculated an index of deviation from uninformed behaviour, which we defined as following the menu layout by clicking each item sequentially along the list, from top to bottom for each fund. The index was zero for participants who followed this pattern precisely, and higher for participants who deviated from the presented order by targeting specific information, with a maximum value of 16 .

There was a significant influence of the search restriction on the deviation index $\left(\chi^{2}(2)=73.33, p<.001\right)$. The deviation was significantly lower in the Control condition $(M=2.75)$ than in the Restricted-10 $(M=4.76, p<.001)$ and Restricted-6 conditions $(M=5.43, p<.001)$. Participants followed the layout of choices very closely when there was no limit to the number of clicks but appear to have considered their search pattern more carefully when their number of clicks was restricted (Figure 1). In the restricted conditions, they prioritized what could arguably be considered the most important information for a pension scheme: long-term returns,

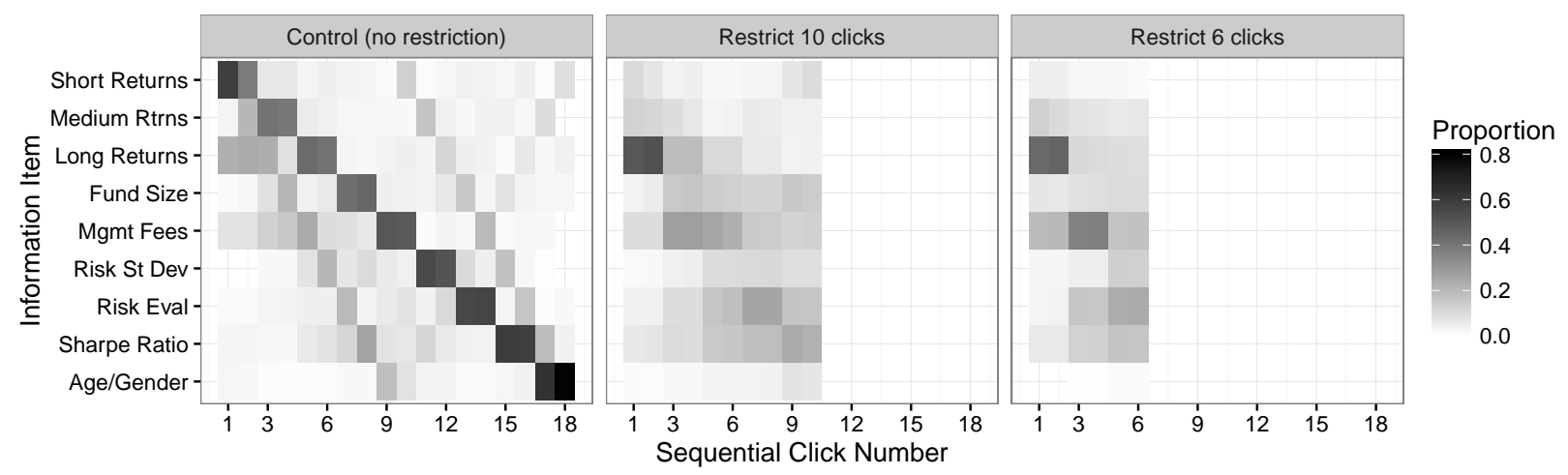

Figure 1. Proportion that each information was revealed at each sequential click number in Experiment 3. The information items are listed in the same order as displayed to participants. The diagonal represents following the provided layout sequentially. 
fees, and risk. Payne et al. (1988) have similarly shown how search constraints helped subjects selectively focus on a subset of information. There was no difference between types of trustees $(p=.09)$.

\section{Discussion}

Our experiments show that the financial decisions made by pension trustees are influenced by extraneous menueffects, instead of following underlying financial principles such as choosing an optimal allocation between bonds and equities, or focusing on long-term returns, fees and risks.

While all trustees were influenced by the mix of choices and the layout of information (Experiments 1 and 3), only the less financially sophisticated member-nominated trustees were influenced by framing (Experiment 2). Shapira and Venezia (2001) also reported that professional experience reduced, but did not eliminate, investment decision biases. Restricting information search, a type of environmental nudge, was also found to help trustees focus on more relevant information.

Fox et al. (2005) suggested that the method of describing the possible alternatives is perceived by the decisionmaker as communicating relevant information, even when it is determined by arbitrary factors. If menu manipulations can influence behaviour as shown here, then care must be given when preparing information to be used by trustees. Advisors, such as investment consultants, should be aware of this to try to reduce biases in trustee decision-making, as such biases are likely to be detrimental to the pension outcomes of members due to inappropriate asset allocation and/or risk-taking. This issue is particularly relevant as the ageing population puts additional pressure on well-managed private pensions to provide retirement income. Policy makers need to understand the influence of choice menus on pension trustees' financial decision-making when designing training for trustees, and we encourage further research in this area.

\section{References}

Barberis, N. C., \& Thaler, R. H. (2003). A survey of behavioral finance. In G. Constantinides, M. Harris, \& R. Stulz (Eds.), Handbook of the economics of finance (pp. 1053-1123). Amsterdam: Elsevier.

Benartzi, S., \& Thaler, R. H. (2001). Naive diversification strategies in defined contribution saving plans. The American Economic Review, 91(1), 79-98.

Benartzi, S., \& Thaler, R. H. (2002). How much is investor autonomy worth? The Journal of Finance, 57(4), 1593-1616.

Clark, G. L., Caerlewy-Smith, E., \& Marshall, J. C. (2007). The consistency of UK pension fund trustee decision-making. Journal of Pension Economics and Finance, 6(1), 67-86.

Dayan, E., \& Bar-Hillel, M. (2011). Nudge to obesity II: Menu positions influence food orders. Judgment and Decision Making, 6(4), 333-342.

Dellavigna, S. (2009). Psychology and economics: Evidence from the field. Journal of Economic Literature, 47(2), 315-372.

Fox, C. R., Ratner, R. K., \& Lieb, D. S. (2005). How subjective grouping of options influences choice and allocation: Diversification bias and the phenomenon of partition dependence. Journal of Experimental Psychology: General, 134(4), 538-551.

Menkhoff, L., Schmeling, M., \& Schmidt, U. (2009). Are all professional investors sophisticated? German Economic Review, 11, 418-440.

Myners, P. (2001). Institutional investment in the United Kingdom: A review. London, UK: HM Treasury.

Payne, J. W., Bettman, J. R., \& Johnson, E. J. (1988). Adaptive strategy selection in decision making. Journal of Experimental Psychology: Learning, Memory, and Cognition, 14(3), 534-552.

Sela, A., Berger, J., \& Liu, W. (2009). Variety, vice, and virtue: How assortment size influences option choice. Journal of Consumer Research, 35(6), 941-951.

Shapira, Z., \& Venezia, I. (2001). Patterns of behavior of professionally managed and independent investors. Journal of Banking and Finance, 25, 1573-1587.

Simonson, I. (1989). Choice based on reasons: The case of attraction and compromise effects. Journal of Consumer Research, 16(2), 158-174.

Vlaev, I., Chater, N., \& Stewart, N. (2007). Financial prospect relativity: Context effects in financial decision-making under risk. Journal of Behavioral Decision Making, 20, 273-304.

West, R. F., Meserve, R. J., \& Stanovich, K. E. (2012). Cognitive sophistication does not attenuate the bias blind spot. Journal of Personality and Social Psychology, 103(3), 506-519. 